УДК 619:618.1:619:612.1:636:2, DOI 10.31210/visnyk2018.02.31

(C) 2018

Басараб Т. П., асистент кафедри акушерства, гінекології та біотехнології відтворення тварин ім. Г. В. Звєрєвої

Львівський національний університет ветеринарної медицини та біотехнологій імені С. З. Гжицького

\title{
МОРФОЛОГІЧНІ ПОКАЗНИКИ КРОВІ КОРІВ ЗА СУБКЛІНІЧНОГО ЕНДОМЕТРИТУ ТА ПІСЛЯ ЙОГО ЛІКУВАННЯ
}

\section{Рецензент - доктор ветеринарних наук, професор Л. Г. Слівінська}

\begin{tabular}{|c|}
\hline 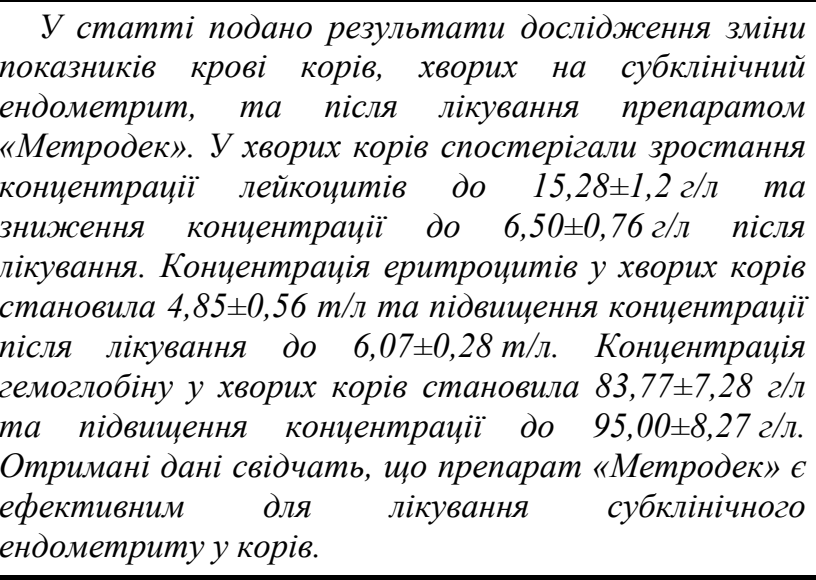 \\
\hline
\end{tabular}

Ключові слова: ендометрит, субклінічний ендометрит, корова, морфологія крові, еритрочичти, лейкочити, гемоглобін, еритропоез, лейкопоез.

Постановка проблеми. Акушерські та гінекологічні захворювання корів викликають довготривалу неплідність. Тому особливу увагу слід звертати на профілактику, діагностику та лікування захворювань репродуктивної системи [6]. Сприяючими чинниками, які викликають ендометрит, $\epsilon$ відсутність оптимальних санітарних умов при отеленні корів та у післяпологовий період. Через несвоєчасну діагностику ендометриту процес переходить у субклінічну форму, що викликає довготривалу неплідність корів [2]. У літературі $\epsilon$ дані щодо впливу гінекологічної патології на відтворювальну функцію - у корів з клінічним або субклінічним ендометритом процент запліднення після одужання був нижчий порівняно зі здоровими коровами [17]. У зв'язку з цим, фермерські господарства мають значні економічні збитки [5].

Аналіз останніх досліджень i публікацій 3 даної проблеми. Ендометрит $\epsilon$ одним iз захворювань, які викликають порушення репродуктивної функції корів, а основним етіологічним фактором у їх розвитку вважають мікроорганізми. Бактеріологічне обсіменіння статевих органів корів у післяпологовий період спостерігають у $90 \%[3,30]$. Перебіг ендометри- ту залежить від інтенсивності мікробного обсіменіння, резистентності та інтоксикації організму, а ефективність лікування - від своєчасної діагностики [2].

Субклінічний ендометрит діагностують на основі анамнестичних даних, вагінального, ректального, ультразвукового, гістероскопічного дослідження матки, бактеріологічного дослідження біоптату ендометрію, цитологічних досліджень мазків-відбитків та біохімічних, морфологічних досліджень крові. Це дає змогу діагностувати ендометрит, визначити його форму та інтенсивність перебігу $[1,12]$.

3 літературних даних відомий простий i доступний метод діагностики субклінічного ендометриту, який полягає в тому, що у хворих тварин при додованні краплі сперми до маткових виділень спостерігали масову аглютинацію спеміїв [3].

Одним із методів діагностики субклінічного ендометриту також вважається метод вагінальної цитології. Він дає певну характеристику функціонального стану статевої системи [8]. За відсутності клінічних ознак ендометриту на 20-33-у та 34-47-у доби після отелу діагноз ставили на основі наявності нейтрофілів у мазках слизової піхви корів: $>18 \%$ і $>10 \%$ відповідно [14]. Окремі автори вказують на непрактичність застосування цього методу у польових умовах [24].

Також доступним методом для діагностики ендометриту є використання реактиву Бенедикта. Зазначається, що достовірність отриманих результатів становить $95 \%$, а метод $є$ доступним для використання в господарствах [11].

Для діагностики стану субінволюції матки, який може бути попередником ендометриту у корів, проводять дослідження лохіальних виділень на вміст сіалових кислот. Їхня концентрація 157-160 у.о., розтяжність $1,0-1,1 \mathrm{~cm}$ та $\mathrm{pH} 7,5-8,1$ вказує на перебіг патологічного процесу [9]. Разом із тим, можна виявляти вміст сіалових кислот, загального білку і білкових фракцій у крові корів, в якій спостерігали значні зміни біохімічного профілю, підвищення вмісту 


\section{СТОРІНКА МОЛОДОГО ВЧЕНОГО}

сіалових кислот протягом усього періоду вагітності у корів, схильних до субінволюції матки $[10,7]$.

Одним із перспективних методів діагностики субклінічного ендометриту $\epsilon$ вимірювання оптичної щільності (довжина хвилі 620 нм) маткових виділень, відібраних шляхом промивання. У разі наявності нейтрофілів та бактерій Trueperella pyogenes відбуваються зміни оптичної щільності, а реакція вважається позитивною [23].

У ветеринарній практиці набуває популярно-сті ультразвукова діагностика матки. Позитивним вважається діагноз за УЗ-картині розширення діаметру просвіту матки з анехогенним вмістом, а також потовщення іiі стінок та зміною ехогенності. Оскільки подібні результати ульрасонографічоного дослідження можуть бути характерними для декількох патологій, цей метод не може використовуватись для остаточного встановлення діагнозу [18, 23]. Метод вагіноскопії $є$ досить інформативним і простим для виконання та у випадку закритої шийки матки вважається неефективним [19].

У літературі зустрічаються дані про показники крові корів у післяпологовий період за ендометриту, порівняльні дані про перебіг клінічного та субклінічного ендометриту [25, 13, $22,4]$. Дослідження цієї патології є актуальними, тому що дають змогу кращого розуміння перебігу змін гематологічних показників крові корів за субклінічного ендометриту [15].

Метою нашої роботи було вивчити зміни показників крові корів за субклінічного ендометриту та після його лікування препаратом «Метродек».

Завданням дослідження було вивчити зміни концентрації лейкоцитів, еритроцитів та гемоглобіну у крові корів за субклінічного ендометриту та після його лікування препаратом «Метродек».

Матеріали і методи. Дослідження проводилось у ННВЦ «Комарнівське» ЛНУВМБ iм. С. 3. Гжицького на двох групах корів української чорно-рябої молочної породи віком від 4 до 7 років. Контрольна група (К) включала шість $(n=6)$ клінічно здорових корів. Дослідна група (Д) включала шість $(\mathrm{n}=6)$ тварин iз субклінічним ендометритом, яких лікували препаратом «Метродек».

Для лікування використовували препарат «Метродек», який містить декаметоксину - 0,15 г, поліетиленоксиду 400 - 1,8 г, поліетиленоксиду 1500 - 7,2 г. Препарат вводили рукою через канал шийки в порожнину матки корів в дозі один супозиторій та повторювали процедуру до повного видужання через кожні 48 годин у цій же дозі.

Відбір крові у корів проводили з яремної вени у стерильні вакуумні пробірки 3 K2 EDTA Venosafe (Бельгія) в перший день статевого циклу у тварин контрольної групи (К), у тварин дослідної групи (Д) - за діагностування субклінічного ендометриту та після лікування в перший день статевого циклу.

Кількість лейкоцитів, еритроцитів та вміст гемоглобіну визначали за допомогою автоматичного гематологічного аналізатора «Orphee Mythic 18» (Швейцарія) 3 використанням реагентів фірми «PZ Cormay S.A.» (Польща).

Статистичну обробку даних проводили за допомогою SPSS (IBM, USA). У випадках, коли тест Шапіро-Уілка вказував на нормальний розподіл даних, вірогідність показників оцінювали за t-критерієм Стьюдента. За ненормального розподілу використовували критерій Манна-Уітні. Статистично значущими вважали відмінності за $\mathrm{P}<0,05$.

Результати досліджень. У результаті наших досліджень встановлено, що у корів із субклінічним ендометритом спостерігали загальне пригнічення їх стану, порушення апетиту, гіперемійовану слизову оболонку піхви, виділення ексудату зі статевих органів, відсутність статевого циклу. В результаті ректального дослідження встановлювали збільшення рогів матки, флуктуацію. При гістероскопічному дослідженні матки відзначали гіперемію 3 крововиливами різної інтенсивності, у просвіті та на стінках спостерігався мутний, тягучий, слизистий ексудат сірого та світлосірого кольору з домішками крові [12].

Після застосування препарату «Метродек» у тварин спостерігали покращення апетиту, підвищення активності тварини, відновлення статевого циклу. При ректальній пальпації відзначали зменшення матки в об'ємі.

При гістероскопічному дослідженні матки після лікування відзначали зміну кольору стінок матки до блідо-рожевого, зменшення кількості ексудату, який був прозорий, інколи злегка каламутний [12].

Проведені дослідження показали (табл. 1), що у крові спостерігали вірогідне підвищення на 130 \% $(\mathrm{P}<0,01)$ концентрації лейкоцитів у корів із субклінічним ендометритом, у порівнянні 3 контрольною групою. та вірогідне зниження концентрації на $42 \% \quad(\mathrm{P}<0,01)$ у корів після лікування, у порівнянні 3 дослідною групою до лікування. 


\section{1. Гематологічні показники крові корів за субклінічного ендометриту та після лікування препаратом «Метродек», $M \pm S D, n=6$}

\begin{tabular}{|c|c|c|c|}
\hline \multirow{2}{*}{ Прупа тварин } & \multirow{2}{*}{ Доказник } & \multicolumn{2}{|c|}{ Дослідна (Д) } \\
\cline { 3 - 4 } & & до лікування & після лікування \\
\hline Лейкоцити, г/л & $6,63 \pm 0,65$ & $15,28 \pm 1,2^{* *}$ & $6,50 \pm 0,76^{\prime \prime}$ \\
\hline Еритроцити, т/л & $6,24 \pm 0,38$ & $4,85 \pm 0,56^{* *}$ & $6,07 \pm 0,28^{\prime \prime}$ \\
\hline Гемоглобін. г/л & $99,67 \pm 4,08$ & $83,77 \pm 7,28^{* *}$ & $95,00 \pm 8,27^{\prime}$ \\
\hline
\end{tabular}

Примітка: ступінь вірогідності порівняно з контрольною (К) групою * $-\mathrm{P}<0,05$; ** $-\mathrm{P}<0,01$; *** - Р < 0,001; ступінь вірогідності порівняно 3 дослідною групою до лікування (Д) групою '- $\mathrm{P}<0,05 ;$; $-\mathrm{P}<0,01 ; " '-\mathrm{P}<0,001$.

Концентрація еритроцитів (табл. 1) у корів із субклінічним ендометритом вірогідно знижувалася на $22 \% \quad(\mathrm{P}<0,01)$, у порівнянні 3 контрольною групою, та вірогідно зростала після лікування на $25 \%(\mathrm{P}<0,01)$, у порівнянні 3 дослідною групою до лікування. Концентрація гемоглобіну (табл. 1) у корів із субклінічним ендометритом вірогідно знижувалася на $16 \%$ $(\mathrm{P}<0,01)$, у порівнянні 3 контрольною групою. та вірогідно зростала на $13 \%(\mathrm{P}<0,05)$, у порівнянні 3 дослідною групою до лікування.

Зменшення концентрації лейкоцитів у післяпологовий період є характерним для корів $\mathrm{i}$ пояснюється їхньою міграцією до просвіту матки та молочної залози [21]. Надалі кількість лейкоцитів відновлювалася і коливалася у межах фізіологічної норми [26].

Ендометрит часто супроводжується персистентним жовтим тілом та порушенням розвитку і дозрівання фолікулів, що викликає зміну співвідношення прогестерон-естроген [3]. Дисбаланс дії гормонів може спричинити зміни показників крові, що пояснюється постійною міграцією клітин захисту до місця запального процесу $[25,27,28,16]$. Під час субклінічного ендометриту ми спостерігали лейкоцитоз. Відомим фактом $\epsilon$ те, що понаднормове збільшення лейкоцитів $\epsilon$ характерним при запальних процесах. Після лікування концентрація лейкоцитів поверталась до норми, що вказує на закінчення запального процесу.

Інфекційний процес в органах репродуктивного тракту може впливати на інші органи, системи та обмін речовин. Нирки вважаються місцем синтезу еритропоетину. За ендометриту вони зазнають

\section{БІБЛІОГРАФІЯ}

1. Ветеринарне акушерство, гінекологія та біотехнологія відтворення тварин 3 основами андрології. / В. А. Яблонський та ін. - Вінниця: Нова Книга, 2006. - 592 с. негативного впливу, що призводить до порушення їх функції $[1,20]$. Еритропоетин є стимулятором еритропоезу, а недостатність цього білка може пояснювати зниження концентрації еритроцитів за субклінічного ендометриту.

Запальні цитокіни діють як інгібітори еритропоезу та пригнічують виживання еритроцитів. IL-1, IL-6 та TNF- $\alpha$ відіграють важливу роль у збільшенні синтезу гепсидину, який, в свою чергу, гальмує всмоктування заліза 3 епітелію шлунково-кишкового тракту та інактивує ферропортин, який відповідальний за транспорт заліза. Ліпосахариди послаблюють дію DMT1 та ферропортину, що послаблює експорт заліза 3 макрофагів та гепатоцитів. IL-10 посилює експресію трансферину, що зумовлює посилення поглинання заліза епітелієм, а TNF- $\alpha$, IL-1, IL-6 та IL-10 посилюють експресію ферритину, що сприяє внутрішньоклітинному збереженню та утриманню заліза $[22,29]$. Ці процеси пояснюють зниження концентрації еритроцитів та гемоглобіну у крові корів під час запального процесу у статевих органах та відновлення концентрації еритроцитів та гемоглобіну після лікування.

Висновок. Отримані дані свідчать, що препарат «Метродек» $\epsilon$ ефективним для лікування субклінічного ендометриту у корів. Ця патологія впливає на морфологічні зміни показники крові і характеризується підвищенням концентрації лейкоцитів, зниженням концентрації еритроцитів та гемоглобіну.

Надалі планується вивчити вплив препарату «Метродек» на біохімічні показники крові корів, експресію цитокінів, гормональних рецепторів та їхній взаємозв'язок.

2. Етіологія розвитку метриту у корів та методи їх лікування / В.Ю. Стефаник та ін. // Науковий вісник ЛНУВМБТ імені С. 3. Гжицького. - 2009. - № 11 (3). - С. 152-157. 


\section{СТОРІНКА МОЛОДОГО ВЧЕНОГО}

3. Етіологія, патогенез, діагностика та методи лікування корів, хворих на метрит / Я. С. Стравський та ін. // Науково-технічний бюлетень Інституту біології тварин і Державного науководослідного контрольного інституту ветпрепаратів та кормових добавок. - 2015. - № 16 (1). С. 257-274.

4. Ефективність лікування післяродового ендометриту корів аерозольним препаратом «Цефген» / О.А. Кацараба та ін. // Науковий вісник ЛНУВМБ імені С. 3. Гжицького. - 2017. № 19 (82). - С. 230-234.

5. Застосування етіотропно-патогенетичної терапії при метритах у корів / Р. М. Івашків та ін. // Науковий вісник ЛНУВМБТ імені С. З. Гжицького. - 2012. - № 16 (1). - С. 71-73.

6. Морфологічна характеристика ендометрію неплідних корів 3 використанням скануючої електронної мікроскопії. / В. Ю. Стефаник та ін. // Науковий вісник ЛНУВМБТ імені С. 3. Гжицького. - 2010. - № 12 (3). - С. 219-227.

7. Стравський Я. С. Вміст загального білка і білкових фракцій у крові корів із фізіологічним перебігом тільності та у корів, схильних до субінволюції матки // Ветеринарна біотехнологія. - 2012. - № 21. - С. 362-366.

8. Стравський Я. С. Діагностичне значення цитологічного методу дослідження мазків слизової піхви коріву післяродовий період // Науковий вісник ЛНУВМБ імені С. 3. Гжицького. - 2009. - № 2 (41). - С. 314-317.

9. Стравський Я. С. Показники лохій корів при субінволюції матки // Ветеринарна біотехнологія. - 2011. - № 20. - С. 185-190.

10. Стравський Я. С., Охрим С. А., Маркова O. П. Діагностично-прогностичне значення вмісту сіалових кислот у крові корів // Науковий вісник ЛНУВМБТ імені С. 3. Гжицького. - 2010. № 2 (44). - С. 315-317.

11. Федорків О. П., Стравський Я. С. Діагностика гострого післяродового ендометриту у корів реактивом Бенедикта // Науковий вісник ЛНУВМБ імені С. 3. Гжицького. - 2015. - № 1 (61). - C. 204-208.

12. Basarab T. P., Stefanyk V. Y. Hysteroscopic investigation of dairy cows uterus with subclinical endometritis // Науковий вісник ЛНУВМБТ імені С. 3. Гжицького. - 2016. - № 18 (3). - Р. 218-220.

13. Blood and intrauterine leukocyte profile and function in dairy cows that spontaneously recovered from postpartum endometritis / L. Mateus et al. // Reprod. Dom. Anim. - 2002. - № 37. - P. 176-180.

14. Defining postpartum uterine disease in cattle / I. M. Sheldon et al. // Theriogenology. - 2006. - № 65. - P. 1516-1530.
15. Definitions and diagnosis of postpartum endometritis in dairy cows / J. Dubuc et al. // J. Dairy Sci. - 2010. - № 93. - P. 5225-5233.

16. Effect of exogenous estrogen on uterine leucocyte recruitment / J. A. DeLoya et al. // Fertil Steril. - 2002. - № 77. - P. 548-554.

17. Effects of endometritis at the beginning of the breeding period on reproductive performance in dairy cows / D. S. Hammon et al. // Am Assoc Bov Pract. - 2001. - № 34. - P. 142-143.

18. Endometrial cytology and ultrasonography for the detection of subclinical endometritis in postpartum dairy cows / R. Kasimanickam et al. // Theriogenology. - 2004. - № 62 - - P. 9-23.

19. Endometritis of dairy cattle: diagnosis, treatment and fertility / H. V. Miller et al. // Bovine Pract. - 1980. - № 5. - P. 13-23.

20. Erythropoietin treatment of the anaemia of myelofibrosis with myeloid metaplasia: results in 20 patients and review of the literature / F. Cervantes et al. // British Journal of Haematology. - 2004. № 127. - P. 399-403.

21. Guidry A. J., Paape M. J., Pearson R. E. Effects of parturition and lactation on blood and milk cell concentrations, corticosteroids, and neutrophil phagocytosis in the cow // Am J Vet Res. - 1976. - № 37. - P. 1195-2000.

22. Hematological changes before and after treatment in dairy cows with clinical and subclinical endometritis / M. Heidarpour et al. // Comp Clin Pathol. - 2012. - № 23. - P. 97-101.

23. Hopper R. M. Bovine Reproduction 1 st ed. USA: John Wiley \& Sons, 2015. - 800 p.

24. LeBlanc $S$. Postpartum uterine disease and dairy herd reproductive performance: a review // Vet J. - 2008. - № 176. - P. 102-114.

25. Nazifi S., Ahmadi M. R., Gheisari H. R. Hematological changes of dairy cows in postpartum period and early pregnancy // Comp Clin Pathol. 2008. - № 17. - P. 157-163.

26. Saad A. M., Concha C., Astrom G. Alterations in neutrophil phagocytosis and lymphocyte blastogenesis in dairy cows around parturition // J Vet Med B. - 1989. - № 36. - P. 337-345.

27. Subandrio A. J., Noakes D. E. Neutrophil migration into the uterine lumen of the cow: the influence of endogenous and exogenous sex steroid hormones using two intrauterine chemoatrtractans // Theriogenology. - 1997. - № 47. - P. 825-835.

28. Subandrio A. L., Sheldon I. M., Noakes D. E. Peripheral and intrauterine neutrophil function in the cow: the influence of endogenous and exogenous sex steroid hormones // Theriogenology. - 2000. № 53. - P. 1591-1608. 
29. Thrall M. A. Veterinary Hematology and Clinical Chemistry. 2nd ed. USA: John Wiley \& Sons, 2012. $-762 \mathrm{p}$.

30. Uterine disease and its effect on subsequent reproductive performance of dairy cattle: a compa-

\section{ANNOTATION}

Basarab T. P. Morphological parameters of cows' blood with subclinical endometritis and after treatment.

Obstetrical and gynecological diseases cause long-term infertility in cows. It is important to pay attention to the prevention, diagnosis and treatment of diseases of the reproductive system. Due to the late diagnosis of endometritis, the process passes into a subclinical form that causes long-term infertility of cows. Endometritis is diseases which accompanied by infertility. The main etiological factor is microorganisms. Subclinical endometritis is diagnosed based on anamnesis, vaginal, rectal, ultrasound, hysteroscopic examination of the uterus, bacteriological examination of endometrial biopsy, cytological examination of smears and biochemical, morphological studies of blood. The aim of our study was to determine morphological changes in blood parameters of cows with subclinical endometritis and after treatment with «Metrodek». There was a significant increase of leukocytes in cows with subclinical endometritis by $130 \%$ $(\mathrm{P}<0.01)$ compared to control group and a significant decrease of leukocytes in cows after treatment by $42 \%(\mathrm{P}<0.01)$ compared with the rison of two cow-side diagnostic methods / M. Љavc et al. // Theriogenology. - 2016. - № 86 (8). P. 1983-1988.

experimental group before treatment. Erythrocytes in cows with subclinical endometritis were significantly lowered by $22 \%(\mathrm{P}<0.01)$ compared to the control group and significantly increased after treatment by $25 \% \quad(\mathrm{P}<0.01) \quad$ compared to the experimental group before treatment. Hemoglobin in cows with subclinical endometritis were significantly lowered by $16 \%(\mathrm{P}<0.01)$ compared to control group and significantly increased by $13 \%$ $(\mathrm{P}<0.05)$ compared to the experimental group before treatment. The course of the disease could be clinically and subclinically endometritis. It depends on the intensity of microbial contamination, intoxication and efficiency of treatment from timely diagnosis. The obtained data indicates that the drug «Metrodeck» is effective in treating subclinical endometritis in cows. This pathology affects morphological changes in the blood parameters and is characterized by an increase in the concentration of leukocytes, a decrease in the concentration of red blood cells and hemoglobin.

Key words: endometritis, subclinical endometritis, cow, blood morphology, erythrocytes, leukocytes, hemoglobin, erythropoiesis, leukopoiesis. 